\title{
ANALISIS KEBIJAKAN DEVIDEN, DER, PBV, DAN PERTUMBUHAN PERUSAHAAN TERHADAP RETURN SAHAM PADA PERUSAHAAN SEKTOR INDUSTRI BARANG KONSUMSI DI BURSA EFEK INDONESIA PERIODE 2016-2020
}

\author{
Destia Aktarina $^{1}$ dan Ike Liana Ernawati ${ }^{2}$ \\ Sekolah Tinggi Ilmu Ekonomi Mulia Darma Pratama \\ e-mail : Destia.aktarina86@gmail.com ${ }^{1}$ ikeliana2@gmail.com² ${ }^{2}$,
}

\begin{abstract}
ABSTRAK
Return saham adalah keuntungan yang diperoleh perusahaan, individu dan institusi dari hasil kebijakan investasi yang dilakukannya. Return saham merupakan income yang diperoleh oleh pemegang saham sebagai hasil dari invetasinya di perusahaan tertentu. Informasi-informasi yang dapat digunakan sebagai tolak ukur tingkat Return saham perusahaan yang diteliti adalah Kebijakan Deviden, Debt To Equity Ratio (DER), Price To Book Value (PBV) dan Pertumbuhan Perusahaan. Tujuan penelitian dalam penelitian ini adalah untuk mengetahui bagaimana perkembangan Kebijakan Deviden, Debt To Equity Ratio (DER), Price To Book Value (PBV), Pertumbuhan Perusahaan dan Return Saham pada perusahaan sektor industri barang konsumsi di BEI periode 2016-2020. Untuk mengetahui bagaimana pengaruh Kebijakan Deviden, Debt To Equity Ratio (DER), Price To Book Value (PBV) dan Pertumbuhan Perusahaan terhadap Return Saham secara parsial dan simultan pada perusahaan sektor indutri barang konsumsi di BEI periode 2016-2020. Metode penelitian yang digunakan dalam penelitian ini yaitu kuantitatif. Metode analisis data menggunakan analisis deskriptif dan verifikatif. Hasil dari penelitian ini menujukkan bahwa secara parsial terdapat pengaruh Kebijakan Deviden, Debt To Equity Ratio (DER), Price To Book Value (PBV) terhadap Return saham, sedangkan Pertumbuhan Perusahaan tidak berpengaruh terhadap Return saham pada perusahaan Sektor Industri Barang Konsumsi di Bursa Efek Indonesia. Hasil penelitian secara simultan menunjukkan bahwa minimal ada satu variabel bebas (Kebijakan Deviden, DER, PBV dan Pertumbuhan Perusahaan) yang berpengaruh terhadap variabel terikat (Return Saham) secara simultan pada perusahaan sektor industri barang konsumsi di BEI periode 2016-2020.
\end{abstract}

Kata Kunci : Kebijakan Deviden, Debt To Equity Ratio (DER), Price To Book Value (PBV), Pertumbuhan Perusahaan dan Return Saham

\begin{abstract}
The profit made by firms, individuals, and institutions as a result of their investing decisions is referred to as stock return. The income received by shareholders as a result of their investment in a company is referred to as stock return. Dividend Policy, Debt To Equity Ratio (DER), Price To Book Value (PBV), and Company Growth are examples of information that can be utilized as a benchmark for the degree of return on the company's shares under investigation. The goal of this study is to see how Dividend Policy, Debt To Equity Ratio (DER), Price To Book Value (PBV), Company Growth, and Stock Returns have changed over time in consumer goods industrial sector companies on the IDX from 2016 to 2020. To determine the impact of Dividend Policy, Debt To Equity Ratio (DER), Price To Book Value (PBV), and Company Growth on Stock Returns partially and simultaneously in the consumer goods industrial sector companies on the IDX from 2016 to 2020. The quantitative research method was applied in this study. The descriptive and verification analytical methods were employed in the data analysis. The findings of this study reveal that dividend policy, debt to equity ratio (DER), and price to book value $(P B V)$ have a partial effect on stock returns in consumer goods industrial sector companies listed on the Indonesia Stock Exchange, but that company growth has no effect on stock returns. In the consumer goods industrial sector companies on the IDX for the 2016-2020 timeframe, simultaneous research results reveal that at least one independent variable (Dividend Policy, DER, PBV, and Company Growth) affects the dependent variable (Stock Return) simultaneously.
\end{abstract}

Keywords : Dividend Policy, Debt To Equity Ratio (DER), Price To Book Value (PBV), Company Growth and Stock Return 


\section{PENDAHULUAN}

Pasar modal merupakan sarana perusahaan untuk meningkatkan kebutuhan dana jangka panjang dengan menjual dan mngeluarkan obligasi. Pasar modal memiliki fungsi sarana alokasi dana dari pemberi pinjaman ke peminjam. (Jogiyanto,2014:29).

Tingkat keuntungan investasi disebut return. Menurut Fahmi (2015:358) return saham adalah keuntungan yang diperoleh perusahaan, individu dan institusi dari hasil kebijakan investasi yang dilakukanya. Return saham merupakan income yang diperoleh oleh pemegang saham sebagai hasil dari invetasinya diperusahaan tertentu.

Menurut Fahmi (2015:86) faktorfaktor yang mempengaruhi return saham adalah:

1. Kondisi makro meliputi inflasi, suku bunga, nilai tukar, valuta asing, tingkat pertumbuhan perusahaan.

2. Kondisi mikro ekonomi meliputi, Earning Psr Share (EPS), Leverage, Dividen Per Share (DPS), Price Earning Ratio (PER), Net Profit Margin (NPM), Price To Book Value (PBV), Economi Value Addad (EVA), Return On Equity (ROE), Debt Equity Ratio (DER), dan Deviden Payout Ratio (DPR).

3. Kinerja perusahaan yang terus mengalami penurunan setiap waktu

4. Risiko sistematis, yaitu suatu bentuk resiko yang terjadi secara menyeluruh dan telah ikut menyebabkan perusahaan ikut terlibat

5. Efek dari psikologi pasar yang ternyata mampu menekan kondisi teknikal jual beli saham

Kebijakan deviden adalah keputusan direksi apakah laba yang diperoleh perusahaan akan dibagikan kepada pemegang saham sebagai deviden atau akan ditahan dalam bentuk laba ditahan guna pembiayaan investasi dimasa yang akan datang. Menurut Agus Sartono (2014:281). Pembayaran deviden yang semakin besar akan mengurangi kemampuan perusahaan untuk investasi sehingga akan menurunkan tingkat pertumbuhan perusahaan dan selanjutnya akan menurunkan harga saham. Hal ini didukung oleh teori deviden relevan menyatakan bahwa terdapat kebijakan deviden optimal bagi suatu perusahaan, yakni rasio pembayaran deviden yang akan memaksimumkan harga saham. Dengan demikian kebijakan deviden dapat mempengaruhi return saham.

Debt To Equity Ratio (DER) adalah perbandingan antara hutang yang dimiliki perusahaan dengan ekuitasnya.

Fahmi (2014:72) Debt To Equity Ratio (DER) merupakan resio leverage yang digunakan untuk mengukur seberapa besar perusahaan di biayai dengan utang. penggunaan utang yang terlalu tinggi akan membahayakan perusahaan, karena perusahaan akan masuk dalam kategori (extream leverage) utang exstrim yaiu perusahaan terjebak dalam tingkat utang yang tinggi dan sulit melepaskan beban utang tersebut. DER memberikan jaminan tentang seberapa besar hutang perusahaan dijamin oleh modal sendiri. Dengan demikian terdapat pengaruh terhadap return saham.

PBV (Price to Book Value) adalah rasio yang menggambarkan perbandingan antara harga pasar saham dan nilai buku equitas sebagaimana yang ada dilaporan posisi keuangan. Rahardjo (2009:80) apabila PBV (Price to Book Value) suatu perusahaan tinggi maka gambaran penilaian pasar pada perusahaan tersebut juga baik, sehingga penilaian investor terhadap perusahaan baik pula. Penilaian investor yang baik akan merubah permintaan saham pada perusahaan, sehingga harga saham akan berubah dan mempengaruhi return saham. Oleh karena itu, didalam memilih saham dengan pertimbangan resio tinggi rendahnya Price to Book Value (PBV) disarankan memilih saham dengan Price to Book Value (PBV) rendah sehingga dapat disimpulkan bahwa Price to Book Value (PBV) memiliki hubungan positif dengan return saham (Jogiyanto, 2003:88).

Pertumbuhan perusahaan adalah aset perusahaan dimana aset merupakan aktiva yang digunakan untuk aktivitas operasional perusahaan. Menurut Safrida (2008:38) 
Pertumbuhan perusahaan sangat diharapkan oleh pihak internal maupun eksternal perusahaan, karena memberikan suatu aspek positif bagi mereka. Dari sudut pandang investor, pertumbuhan suatu perusahaan merupakan suatu tanda perusahaan memiliki aspek yang menguntungkan, dan mereka mengharapkan tingkat pengembalian dari investasi mereka memberikan hasil yang lebih baik, sehingga pengukurannya pertumbuhan perusahaan berpengaruh terhadap return saham.
Pada penelitian ini, peneliti memilih sektor Industri Barang Konsumsi yang terdiri dari 6 sub sektor yaitu, kosmetik dan rumah tangga, makanan dan minuman, peralatan rumah tangga, farmasi, pabrik tembakau dan lain-lain. Terdapat 54 perusahaan manufaktur yang termasuk dalam Sektor Industri Barang Konsumsi. Namun dalam penelitian ini peneliti hanya memilih 7 perusahaan dengan kriteria yang telah ditentukan untuk dijadikan sampel.

Tabel 1

Data Harga Saham Perusahaan Manufaktur Sektor Industri Barang Konsumsi

Di Bursa Efek Indonesia Periode 2016-2020.

\begin{tabular}{|c|c|c|c|c|c|c|}
\hline \multirow[t]{2}{*}{ No } & \multirow{2}{*}{$\begin{array}{c}\text { Kode } \\
\text { Emiten }\end{array}$} & \multicolumn{5}{|c|}{ Harga Saham } \\
\hline & & 2016 & 2017 & 2018 & 2019 & 2020 \\
\hline 1 & KLBF & 1515 & 1690 & 1520 & 1610 & 1480 \\
\hline 2 & DYLA & 1755 & 1960 & 1940 & 2250 & 2410 \\
\hline 3 & TSPC & 1970 & 1800 & 1390 & 1395 & 1400 \\
\hline 4 & UNVR & 38800 & 55900 & 45400 & 42000 & 7450 \\
\hline 5 & INDF & 7925 & 7625 & 7450 & 7925 & 6850 \\
\hline 6 & KINO & 3030 & 2120 & 2800 & 3430 & 2720 \\
\hline 7 & MYOR & 1645 & 2020 & 2620 & 2050 & 2710 \\
\hline
\end{tabular}

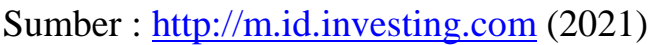

Dari tabel 1 dapat di ketahui data harga saham pada perusahaan industri barang konsumsi setiap tahunnya mengalami fluktuasi (naik turun). Seperti pada PT. Kalbe Indonesia Tbk. Harga tertinggi pada tahun 2017 senilai Rp. 1690 dan terendah pada tahun $2020 \mathrm{Rp} .1480$. PT. Darya Varia Laboratoria Tbk tertinggi pada tahun 2020 senilai Rp. 2410 dan terentah pada tahun 2016 senilai Rp. 1755. PT. Tempo Scan Pacific Tbk. Tertinggi pada tahun 2016 senilai Rp. 1970 dan terendah pada tahun 2018 senilai Rp. 1390. PT. Unilever Indonesia Tbk. Tertinggi pada tahun 2017 senilai Rp. 55900 dan terendah pada tahun 2020 senilai Rp. 7450. PT. Indofood Sukses Makmur Tbk. Tertinggi pada tahun 2016 dan 2019 senilai Rp. 7925 dan terendah pada tahun 2020 senilai Rp. 6850. PT. Kino Indonesia Tbk Tertinggi pada tahun 2019 senilai 3430 dan terendah pada tahun 2017 senilai 2120. PT. Mayora Indah Tbk tertinggi pada tahun 2020 senilai 2710 dan terendah pada tahun 2016 senilai 1645 .

Berdasarkan uraian latar belakang diatas peneliti tertarik untuk meneliti dengan judul "ANALISIS KEBIJAKAN DEVIDEN, DER, PBV DAN PERTUMBUHAN PERUSAHAAN TERHADAP RETURN SAHAM PADA PERUSAHAAN SEKTOR INDUSTRI BARANG KONSUMSI DI BURSA EFEK INDONESIA PERIODE 2016-2020".

\section{METODOLOGI PENELITIAN}

\subsection{Retun Saham}

Menurut Fahmi (2015:358) return saham adalah keuntungan yang diperoleh perusahaan, individu dan institusi dari hasil kebijakan investasi yang dilakukanya. Return saham merupakan income yang diperoleh oleh pemegang saham sebagai hasil dari invetasinya diperusahaan tertentu. Return saham dapat diukur dengan rumus : 


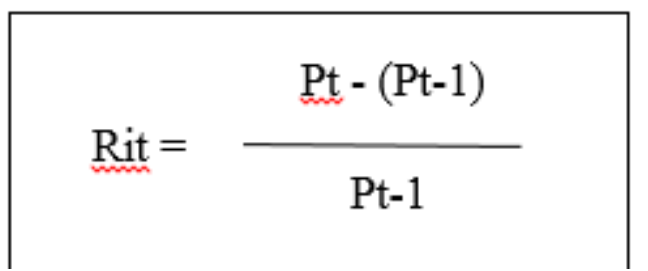

Sumber : Jogiyanto Hartono (2013 : 306)

\subsection{Kebijakan Deviden}

Menurut Martono

(2012:270)

kebijakan deviden (dividend policy) merupakan keputusan apakah laba yang diperoleh perusahaan pada akhir tahun akan dibagi kepada pemegang saham dalam bentuk deviden atau akan ditahan untuk menambah modal guna pembiayaan investasi dimasa akan datang. Deviden Payout Ratio (DPR) dapat dirumuskan sebagai berikut :

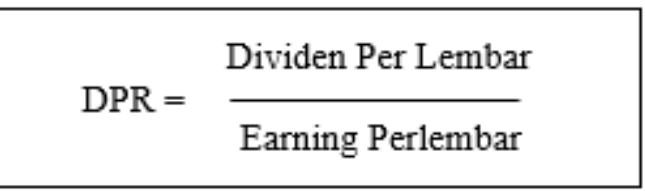

Sumber : Agus Sartono (2014.282)

\subsection{Debt To Equity Ratio (DER)}

Menurut Fahmi (2014:72) Debt To

Equity Ratio (DER) merupakan resio leverage yang digunakan untuk mengukur seberapa besar perusahaan di biayai dengan utang. Rumus untuk menghitung Debt to Equity Rasio dapat digunakan perbandingan antara total utang dengan ekuitas sebagai berikut :

DER $=\frac{\text { Total Utang }}{\text { Equitas Pemegang Saham }}$

Sumber : Kasmir (2014 : 158)

\subsection{Price To Book Value (PBV)}

Menurut Tandelilin, (2010:194)

PBV (Price to Book Value) adalah hubungan antara harga pasar saham dan nilai buku per lembar saham bisa juga dipakai sebagai penekatan alternatif untuk menentukan nilai suatu saham, karena secara teoritis nilai pasar suatu saham haruslah mencerminkan nilai bukunya. Untuk menghitung PBV (Price To Book

Value) dapat digunakan rumus sebagai berikut :

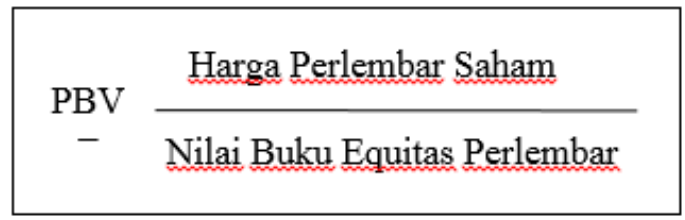

Sumber : Sawir (2005:21)

\subsection{Pertumbuhan Perusahaan}

Safrida, (2008:34) pertumbuhan perusahaan merupakan total aset dimana pertumbuhan aset masa lalu akan menggambarkan profitabilitas yang akan datang dan pertumbuhan yang datang, growth adalah perubahan (penurunan atau peningkatan) total aktiva yang dimiliki oleh perusahaan. Untuk menghitung pertumbuhan perusahaan dapat digunakan rumus sebagai berikut :

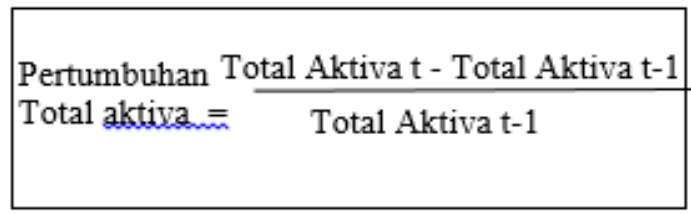

Sumber : Safrida ( $2008: 34$ )

\section{METODE PENELITIAN}

3.1 Objek Penelitian

Objek penelitian ini adalah Data Laporan Keuangan dan Harga Saham pada perusahaan sektor industri barang konsumsi di BEI periode 2016-2020.

\subsection{Metode Penelitian}

Dalam penelitian ini penulis menggunakan metode kuantitatif. Penelitian kuantitatif merupakan penelitian yang menunjukkan hubungan sebab dan akibat antara dua variabel atau lebih. Tujuan dari penelitian ini yaitu untuk melihat pengaruh suatu variabel terhadap variabel lainnya. Sugiyono (2019:16).

\subsection{Metode Analisis Data}

Metode analisis data yang digunakan dalam penelitian ini adalah metode deskriptif dan metode verifikatif dilakukan dengan langkah-langkah sebagai berikut :

1. Untuk menjawab Perumusan Masalah Pertama langkah-langkah yang dilakukan adalah menganalisis perkembangan dari masing-masing variabel ( kebijakan 
deviden, debt to equity ratio, price to book value, pertumbuhan perusahaan dan return saham )

2. Untuk Menjawab Perumusan Masalah Kedua langkah-langkah yang dilakukan adalah membuat model hubungan Kebijakan Deviden $\left(\mathrm{X}_{1}\right)$, Debt To Equity Ratio $\left(\mathrm{X}_{2}\right)$, Price To Book Value $\left(\mathrm{X}_{3}\right)$ dan Pertumbuhan Perusahaan $\left(\mathrm{X}_{4}\right)$ terhadap Return Saham (Y) dengan regresi linier berganda serta melakukan Uji Parsial ( uji statistik t )
3. Untuk Menjawab Perumusan Masalah Ketiga langkah-langkah yang dilakukan adalah melakukan uji koefisien determinasi $\left(\mathrm{R}^{2}\right)$ serta melakukan uji secara simultan (uji statistik F)

\section{HASIL DAN PEMBAHASAN}

\subsection{Hasil Analisis Regresi Linier Berganda}

Berdasarkan hasil output software SPSS ver.25 pada tabel 2 didapatkan persamaan regresi linier berganda sebagai berikut :

$$
Y=22609,162-0,012 X_{1}-0,473 X_{2}+0,003 X_{3}+0,205 X_{4}+e
$$

Tabel 2

Coefficients*

\section{Hasil Analisis Regresi Linier Berganda}

\begin{tabular}{|c|c|c|c|c|c|c|c|}
\hline \multirow[t]{2}{*}{ Model } & \multicolumn{2}{|c|}{$\begin{array}{l}\text { Unstandardized } \\
\text { Coefficients }\end{array}$} & \multirow{2}{*}{$\begin{array}{c}\begin{array}{c}\text { Standar } \\
\text { dized } \\
\text { Coeffisi } \\
\text { ents }\end{array} \\
\text { Beta }\end{array}$} & \multirow[t]{2}{*}{$\mathrm{T}$} & \multirow[t]{2}{*}{ Sig. } & \multicolumn{2}{|c|}{$\begin{array}{l}\text { Collincarity } \\
\text { Statistik }\end{array}$} \\
\hline & B & $\begin{array}{l}\text { Std. } \\
\text { Eror }\end{array}$ & & & & $\begin{array}{c}\text { Tolera } \\
\text { nce }\end{array}$ & Vip \\
\hline $\begin{array}{c}\text { (Constantart } \\
\text { ) }\end{array}$ & $\begin{array}{c}22609,1 \\
62\end{array}$ & $\begin{array}{c}10727.3 \\
26\end{array}$ & & 2.108 & ,004 & & \\
\hline $\mathrm{DPR} \%$ &,- 012 &, 005 &,- 332 & -2.427 & ,021 & ,881 & 1,135 \\
\hline DER $\%$ &,- 473 &, 121 &,- 836 & $-3,893$ &, 001 & ,358 & 2,793 \\
\hline PBV\% &, 003 &, 000 & 1.212 & 5.434 &, 000 & ,332 & 3,013 \\
\hline $\begin{array}{c}\text { PERTUMB } \\
\text { UHAN\% }\end{array}$ & ,205 & ,463 &, 057 & ,443 & ,661 & 987 & 1,013 \\
\hline
\end{tabular}

Sumber : Data diolah SPSS, 2021

a. DependevVariabel : RETURN (Y)

Dari hasil analisis regresi linier berganda diartikan sebagai berikut :

1. Nilai Konstanta (a) adalah sebesar 22609,162 menunjukkan jika semua variabel independen (kebijakan deviden, Debt To Equity Ratio, Price To Book Value dan Pertumbuhan Perusahaan) nilainya 0 maka variabel dependen (Return) Saham nilainya sebesar 22609,162 .

2. Nilai koefisien regresi variabel Kebijakan Deviden $\left(b_{1}\right)$ adalah sebesar $-0,012$ berarti setiap peningkatan Kebijakan Deviden sebesar satu maka akan menurunkan Return saham sebesar 0,012 satuan dengan asumsi variabel independen lain nilainya konsta. 
3. Nilai koefisien regresi variabel Debt To Equity Ratio $\left(\mathrm{b}_{2}\right)$ adalah sebesar -0,473 berarti setiap peningkatan Debt To Equity Ratio sebesar satu satuan maka akan menurunkan Return saham sebesar 0,473 satuan dengan asumsi variabel independen lain nilainya konstan.

4. Nilai koefisien regresi variabel Price To Book Value $\left(\mathrm{b}_{3}\right)$ adalah sebesar 0,003 berarti setiap peningkatan Price To Book Value sebesar satu satuan maka akan meningkatkan Return saham sebesar 0,003 satuan dengan asumsi variabel independen lain nilainya konstan

5. Nilai koefisien regresi variabel pertumbuhan perusahaan $\left(b_{4}\right)$ adalah sebesar 0,205 artinya setiap peningkatan pertumbuhan perusahaan sebesar satu satuan maka akan meningkatkan Return saham sebesar 0,205 satuan dengan asumsi variabel independen lain nilainya konstan.

\subsection{Hasil Uji Parsial (Uji t)}

1. Penguji Koefisien Kebijakan Deviden

Dimana dilihat dari output didapat thitung sebesar -2,108 dan $t_{\text {tabel }}$ yang dapat dilihat pada tabel statistik dengan signifikan $0,05 / 2=0,025$ (uji dua sisi) dengan derajat kebebasan $\mathrm{df}=\mathrm{n}-\mathrm{k}-1$ atau $35-4-1=30$ hasil yang diperoleh untuk $t_{\text {tabel }}$ sebesar 2,042. Jadi nilai $t_{\text {hitung }}<t_{\text {tabel }}(-2,108<2,042)$ dan signifikasi $<0,05(0,021<0,05)$, maka $\mathrm{H}_{0}$ ditolak atau menerima $\mathrm{H}_{\mathrm{A}}$. Hal ini menunjukkan bahwa variabel Kebijakan Deviden (DPR) secara parsial berpengaruh signifikan terhadap return saham pada perusahaan sektor industri barang konsumsi di Bursa Efek Indonesia periode 2016-2020.

\section{Penguji Koefisien Debt To Equity Ratio}

Dimana dilihat output didapat thitung sebesar 3,893 dan tabel yang dapat dilihat pada tabel statistik dengan signifikan $0,05 / 2=0,025$ (uji dua sisi) dengan derajat kebebasan $\mathrm{df}=\mathrm{n}-\mathrm{k}-1$ atau $35-4$ $1=30$ hasil yang diperoleh untuk $t_{\text {tabel }}$ sebesar 2,042. Jadi nilai thitung $<t_{\text {tabel }}(-3,893<2,042)$ dan signifikasi $<0,05(0,001<0,05)$, maka $\mathrm{H}_{0}$ ditolak atau menerima $\mathrm{H}_{\mathrm{A}}$. Hal ini menunjukkan bahwa variabel Debt To Equity Ratio secara parsial berpengaruh signifikan terhadap return saham pada perusahaan sektor industri barang konsumsi di Bursa Efek Indonesia periode 2016-2020.

\section{Penguji Koefisien Price To Book Value}

Dimana dilihat output didapat thitung sebesar 5,434 dan tabel yang dapat dilihat pada tabel statistik dengan signifikan $0,05 / 2=0,025$ (uji dua sisi) dengan derajat kebebasan $\mathrm{df}=\mathrm{n}-\mathrm{k}-1$ atau $35-4$ $1=30$ hasil yang diperoleh untuk $t_{\text {tabel }}$ sebesar 2,042. Jadi nilai $t_{\text {hitung }}<t_{\text {tabel }}(5,434>2,042)$ dan signifikasi $<0,05(0,000<0,05)$, maka $\mathrm{H}_{0}$ ditolak atau menerima $\mathrm{H}_{\mathrm{A}}$. Hal ini menunjukkan bahwa variabel Price To Book Value secara parsial berpengaruh signifikan terhadap return saham pada perusahaan sektor industri barang konsumsi di Bursa Efek Indonesia periode 2016-2020.

\section{Penguji Koefisien Pertumbuhan Perusahaan}

Dimana dilihat output didapat thitung sebesar 0,443 dan tabel yang dapat dilihat pada tabel statistik dengan signifikan $0,05 / 2=0,025$ (uji dua sisi) dengan derajat kebebasan $\mathrm{df}=\mathrm{n}-\mathrm{k}-1$ atau $35-4$ $1=30$ hasil yang diperoleh untuk $t_{\text {tabel }}$ sebesar 2,042. $\mathrm{t}$ hitung berada didaerah penerimaan $\mathrm{H}_{0}$ yaitu $2,042<$ Jadi nilai $t_{\text {hitung }}<\mathrm{t}_{\text {tabel }}(0,443<2,042)$ dan signifikasi $<0,05(0,661>0,05)$, maka $\mathrm{H}_{0}$ diterima atau menolak $\mathrm{H}_{\mathrm{A}}$. Hal ini menunjukkan bahwa variabel Pertumbuhan Perusahaan secara parsial tidak berpengaruh signifikan terhadap return saham pada perusahaan sektor industri barang konsumsi di Bursa Efek Indonesia periode 2016-2020. 


\subsection{Hasil Uji Simultan (Uji F)}

Berikut hasil uji simultan (Uji F) yang dapat dilihat pada tabel 3 sebagai berikut :

Tabel 3

Hasil Uji Simultan (Uji F)

\begin{tabular}{|l|l|l|l|l|l|}
\hline Model & $\begin{array}{l}\text { Sum Of } \\
\text { Squares }\end{array}$ & Df & Mean Square & F & Sig. \\
\hline Regression & $3.369 \mathrm{E}+10$ & 4 & 88421941016 & 7,649 &, $000^{\mathrm{b}}$ \\
\hline Residual & $3.303 \mathrm{E}+10$ & 30 & 1100992357 & & \\
\hline Total & $6.672 \mathrm{E}+10$ & 34 & & & \\
\hline a Dependent Variabel : RETURN (Y) \\
b Predictor : (Constant), Kebijakan Deviden (X1), DER (X2), PBV (X3) dan Pertumbuhan \\
Perusahaan (X4) \\
Sumber : Data diolah SPSS, 2021
\end{tabular}

Hasil penelitia ini menunjukkan bahwa nilai $F_{\text {hitung }}$ sebesar 7,649 dan nilai signifikan sebesar $0,000, F_{\text {tabel }}$ yang dapat dilihat pada tabel statistik dengan tingkat signifikan sebesar 0,05 dengan $\mathrm{df}_{1 \mathrm{n}}=$ (jumlah variabel -1$)$ atau $5-1=4 . \mathrm{df}_{2 \mathrm{n}}=(\mathrm{n}-\mathrm{k})$ atau $35-5=30, \mathrm{~F}_{\text {tabel }}$ adalah 2,69, dengan demikian dapat diartikan bahwa $F_{\text {hitung }}>F_{\text {tabel }}(7,649>2,69)$ dengan tingkat signifikasi $<0,05(0,000<0,05)$. Sehingga $\mathrm{H}_{0}$ ditolak atau menerima $\mathrm{H}_{\mathrm{A}}$ artinya minimal ada satu variabel bebas ( Kebijakan Deviden, DER, PBV dan Pertumbuhan Perusahaan ) yang berpengaruh terhadap variabel terikat ( Return Saham ) pada perusahaan sektor industri barang konsumsi di BEI periode 2016-2020.

Tabel 4

Hasil Analisis Koefisien Determinasi $\left(\mathbf{R}^{2}\right)$

Model Summary*

\begin{tabular}{|l|l|l|l|l|l|}
\hline Model & R & R Square & $\begin{array}{l}\text { Adjusted R } \\
\text { Square }\end{array}$ & $\begin{array}{l}\text { Std. Error of } \\
\text { the Estimate }\end{array}$ & $\begin{array}{l}\text { Durbin } \\
\text { Watson }\end{array}$ \\
\hline 1 &, $711^{\mathrm{a}}$ &, 505 &, 439 & 33181,20487 & 2,214 \\
\hline
\end{tabular}

a. Predictors : (constant),PERTUMBUHAN(X4), PBV(X3), DER(X4), DPR(X1

b. Dependent Variabel : RETURN (Y)

Sumber : Data diolah : SPSS, 2021

\section{KESIMPULAN DAN SARAN}

\subsection{Kesimpulan}

1. Hasil uji $\mathrm{t}$ menunjukkan bahwa Kebijakan Deviden, Debt To Equity Ratio (DER), Price To Book Value (PBV) berpengaruh terhadap Return Saham. Sedangkan Pertumbuhan Perusahaan tidak berpengaruh terhadap Return Saham.

2. Hasil uji $\mathrm{F}$ menunjukkan bahwa minimal ada satu variabel bebas (Kebijakan Deviden, Debt To Equity Ratio (DER),
Price To Book Value (PBV) dan Pertumbuhan Perusahaan) yang berpengaruh terhadap variabel terikat (Return Saham) pada perusahaan sektor industri barang konsumsi di BEI periode 2016-2020

3. Nilai Koefisien Determinasi (R Square) dilihat bahwa nilai koefisien determinasi (Adjusted $R$ Square ) adalah sebesar 0,439 (43,9\%). Dengan kata lain, pengaruh variabel bebas (Kebijakan Deviden, DER, PBV dan Pertumbuhan Perusahaan) terhadap variabel terikat 
(Return Saham) adalah sebesar 43,9\% sisanya $56,1 \% \% \quad(100 \% \quad-\quad 43,9 \%)$ dipengaruhi oleh variabel lain yang tidak diteliti dalam penelitian ini.

\subsection{Saran}

Saran yang dapat peneliti sampaikan berdasarkan hasil penelitian yang dilakukan adalah sebagai berikut :

1. Bagi Perusahaan

Perusahaan diharapkan untuk memberikan informasi keuangan yang objektif, relevan dan dapat diuji keabsahannya.

2. Bagi Investor

Bagi investor maupun calon investor yang ingin berinvestasi pada pasar modal hendaknya mempertimbangkan analisis Kebijakan Deviden, Debt To Equity Ratio, Price To Book Value, Pertumbuhan Perusahaan dan juga faktor-faktor lain yang mempengaruhi Return Saham.

3. Bagi Peneliti Lainnya

Bagi peneliti selanjutnya disarankan untuk menambah jumlah sampel penelitian, penambahan periode pengamatan dan menambah jumlah rasio keuangan lainnya seperti Earning Psr Share (EPS), Leverage, Dividen Per Share (DPS), Price Earning Ratio (PER), Net Profit Margin (NPM), Economi Value Addad (EVA), Return On Equity (ROE) dan faktor keuangan lainnya yang memungkinkan mempengaruhi Return Saham dan mengaplikasikannya untuk sektor lain tidak menutup kemungkinan akan memperoleh hasil yang berbeda karena setiap industri memiliki karakteristik yang berbeda.

\section{DAFTAR PUSTAKA}

Agus Harjito dan Martono. 2012, Manajemen Keuangan . Edisi ke2. Ekonisia, Yogyakarta.

Fahmi, Irham. 2015. Manajemen Investasi. Jakarta: Salemba Empat.

. 2015. Manajemen Keuangan. Jakarta: Salemba Empat.

Jogiyanto, H.M. 2000. Teori Portofolio dan Analisis Investasi. Edisi Kedua. BPFE. Yogyakarta.

Jogiyanto, H.M. 2003. Teori Portofolio dan Analisis Investasi. Edisi Ketiga. BPFE. Yogyakarta.

Jogiyanto, H.M. 2010. Teori Portofolio dan Analisis Investasi. Edisi Ketujuh. BPFE. Yogyakarta.

Jogiyanto, H.M. 2011. Metedologi Penelitian Bisnis. Edisi Keempat. BPFE. Yogyakarta.

Kasmir, 2015. Analisis Laporan Keuangan. Jakarta: Salemba Empat.

Rahardjo, Budi. 2009. Laporan Keuangan Perusahaan. Gadja Mada University Press. Yogyakarta.

Safrida,Eli. 2008. Pengaruh Struktur Modal dan Pertumbuhan Perusahaan Nilai Perusahaan Pada Perusahaan Manufaktur di BEI. Thesis, Ilmiah; Binus.ac.id.

Sartono,Agus. 2014. Manajemen Keuangan, Teori Aplikasi. Edisi Empat. Yogyakarta: BPFE.

Sawir, Agnes . 2005. Analisis Kinerja Keuangan dan Perencanaan Keuangan Perusahaan. Jakarta: PT. Gramedia Pustaka Utama.

Sugiyono. 2019. Metode Penelitian Kuantitatif Kualitatif. Bandung: Alfabeta.

Tandelilin, Eduardus. 2010. Portofolio dan Investasi Teori dan Aplikasi. Edisi Pertama.Yogyakarta: PT Kanisius. 